\title{
Analysis of the skilled work force effect on the logistics performance index-case study from India
}

\author{
Amrita Jhawar $\cdot$ S. K. Garg $\cdot$ Shikha N. Khera
}

Received: 14 October 2013/Accepted: 2 June 2014/Published online: 17 June 2014

(C) The Author(s) 2014. This article is published with open access at Springerlink.com

\begin{abstract}
The purpose of this paper is to study the impact of development of skilled work force through investment in training, welfare, working conditions, and wages on the logistics performance index. It also discusses the effect of skilled labour on logistics cost, logistics time, reliability, flexibility, and safety of a logistics system. The paper is based on a case study conducted on an Indian Logistics Service provider. A causal loop diagram and the stock and flow diagram have been developed according to system dynamics modelling principles. The simulation result shows significant improvement in the logistics performance index. The reduction in logistics cost and logistics time is $12 \%$ and $80 \mathrm{~min}$, respectively. With training provided to $36 \%$ employees of the company, the retention rate improved by $58 \%$ and score of recruitment reached to 4.4 out of five. The paper shows that investment done in human resources in the Indian logistics sector will help the logistics service providers and their customers in terms of improved logistics performance and higher profits and will also improve the image attractiveness of the Indian logistics industry.
\end{abstract}

Keywords Human resources - Indian logistics industry . Logistics performance index - System dynamics - Causal loop diagram

A. Jhawar $(\varangle) \cdot$ S. K. Garg · S. N. Khera

Delhi School of Management, Delhi Technological University,

Shahbad Daulatapur, Main Bawana Road,

New Delhi 110042, India

e-mail: ajhawar1@gmail.com

\section{Introduction}

\subsection{Importance of logistics}

Over the past decades, globalization has caused an expansion in trade, leading to the growing strategic importance of the logistics function within the organization. At present, improvements in logistics have been the primary source of increased profits for companies, allowing them to maintain their competitive advantage [24]. Logistics have become important source of sustainable competitive advantage $[8,18,39]$.

Logistics concern the efficient transfer of goods from the source of supply through the place of manufacture to the point of consumption in a cost-effective way while providing an acceptable service to the customer [21]. The chartered institute of logistics and transport (CILT) in the UK describes logistics as getting the right product to the right place in the right quantity at the right time in the best condition and at an acceptable cost [26]. The Council of Supply Chain Management Professionals (2007) defines logistics management as that part of the supply chain management processes, which plans, implements, and controls the efficient, effective forward and reverse flow and storage of goods, services, and related information between the point of origin and the point of consumption in order to meet customers' requirements [17].

With the world economy changing and globalization is overpowering, world is becoming an open market. It becomes necessary for every company to response quickly to consumer demands, reduce lead times, maintain quality at the right cost, and be flexible to achieve the competitive advantage. And the solution to achieve this is to have and efficient logistics system. Having good logistics infrastructure and culture is becoming a prerequisite for 


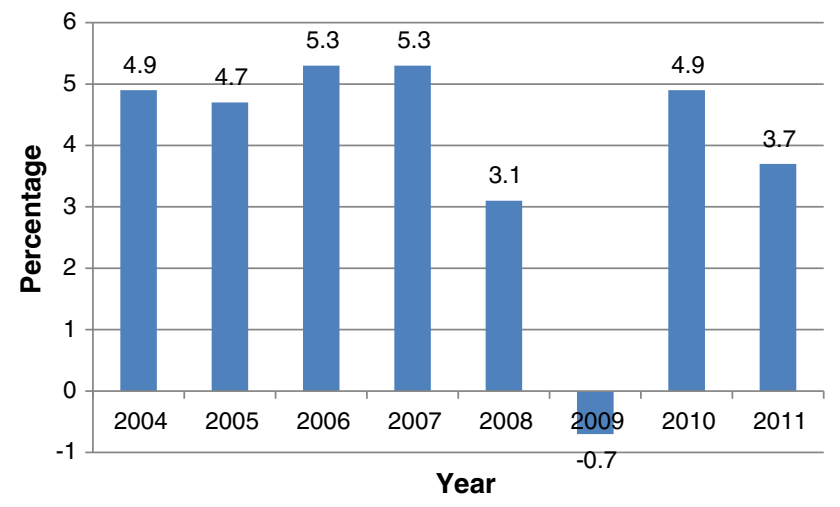

Fig. 1 World GDP growth rate [20]

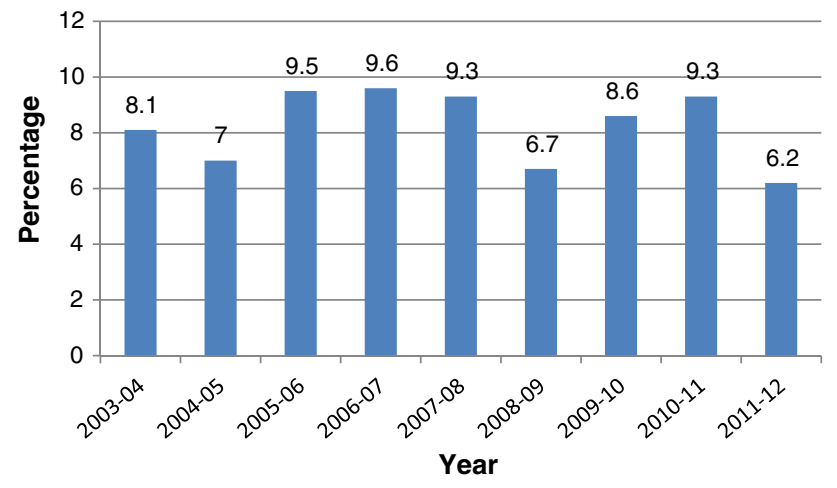

Fig. 2 Indian GDP growth rate [10]

attracting global manufacturing and service companies into the country [46]. Figure 1 shows the growth rate of the world economy. The Indian GDP is growing steadily at 5 to $6 \%$ compared with the world GDP growth rate of $3 \%$ (refer Fig. 2), which is one of the biggest motivation for India to improve its logistics infrastructure so as to attract foreign investors and enhance global trade.

Growth of any economy relies on the trade, exports, imports, manufacturing, primary and secondary industries, etc. With trade, it also relies on the infrastructure and facilities the country possesses. All these factors have a direct and huge impact on the businesses of the country. An investment of $\$ 1,025$ billion is targeted over the duration of the twelfth five year plan (2012-17) in infrastructure development in order to sustain a real GDP growth rate of 9 per cent [10]. Despite this increase, the country's infrastructure network will be insufficient as freight movement increases about three fold in the coming years, and this shortfall will put India's growth at risk [28].

To run a well-knit and sophisticated logistics system, skilled human resources is required and proactive efforts need to be made to develop it. Human resource is a group of individuals working together towards a unique vision and mission to achieve a common goal for organizational growth [2]. Competitive advantage would be gained through the systemic benefits of shared HR practices such as selection, training, and performance management that improve overall supply chain performance [19].

The number of skilled personnel required in India to support the smooth functioning of the logistics network is likely to increase from less than 10 million in 2011 to 20 million by 2020 , including 100,000 warehouse managers, five million truck drivers, and 70,000 coastal seafarers [28].

Logistics, till recent times, was considered as operational function rather than strategic. Also, it is considered as a low-level job. The logistics job in India is still not an option for an educated person, because of the poor image of the industry and harsh-working conditions. The need of the hour is to turnaround the image of the sector by investing in training, making it more organized, granting it the status of an industry, so that skilled professionals will be readily available to make the system more reliable and safe. The skill development of the employees can be attained by means of providing training and education to employee, maintaining safe and pleasant working environment, treating all employees fairly and consistently, encouraging participation through teambuilding, open communication and mutual respect [35].

The logistics performance index was the term coined by the World Bank [4]. It is a comprehensive index created to help countries identify the challenges and opportunities they face in trade logistics performance. The LPI assesses the performance of countries in the following areas and is an equally weighted average of these six components. They are namely customs, infrastructure, international shipments, logistics competence, tracking and tracing and timeliness, which affect the supply chain performance measures measured in terms of time, cost, reliability, and flexibility [5]. Also, as safety plays a major role in supply chain and logistics performance, the authors have added one more performance measure as safety (Fig. 3).

The six factors discussed above can be broadly classified into infrastructure, government regulation and information technology, which cannot function independently without proficient human resources. Therefore, the paper identifies factors that influence the logistics performance and thus the competitiveness of organizations classifying them as enablers and results. Enablers will be the factors that enable to achieve the results or to improve the logistics performance to help organizations to achieve the competitive edge. Results are basically the competitiveness factors that influence the logistics cost and are influenced by the enablers. Thus, LPI is the summation of all factors classified as results. This paper considers one of the enablers' namely 


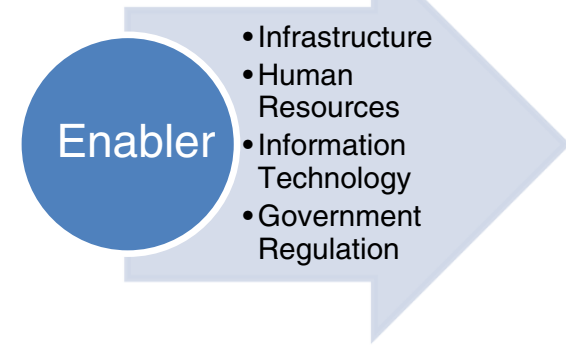

Fig. 3 Relationship between Enablers, Results and LPI

human resources to study the influence of this enabler on LPI. Further, the study also includes the variables that create the human resource namely investment in training, investment in improving the service conditions, leading to development of skilled work force.

\subsection{Logistics Scenario in India}

Logistics industry around the globe is valued about US\$ 3.5 trillion, out of which India's share is US\$ 90 billion [31]. The sector provides employment to about 45 million people in the country, which is more than the information technology (IT) and information technology enabled services (ITES) sectors put together [2]. In 2011, 7.3 million truck drivers were working in the logistics sector in India. It is predicted, that with growing trade this number will increase to 25 million in 2022 [47]. According to a report by KPMG [23], from a survey done on 80 logistics company, it was found that the manpower costs forms $8-10 \%$ of overall cost in the sector (in case of road logistics it is $4 \%$ ). This roughly translates to about Rs. 500 billion spent on logistics manpower annually. Of this, only $13-14 \%$ is spent on nonsalary expenses such as manpower development items such as welfare, training, which is very less compared with global logistics countries, which spend more than $20 \%$.

The availability of skilled work force in the logistics sector is scarce, leading to improper handling of products, rash driving, losses, and separate person for each activity rather than multitasking, lower standard of living, etc. At management and mid-tier levels, the logistical sector in India suffers from organizational skills, lack of leadership, disjointed skills, and positions and lack of process-driven systems [25]. This shortage is present at all the three levels management, managerial, operational, and strategic. The industry is highly unattractive due to its poor image, extreme working conditions, lack of infrastructural facilities, low pay scale, and lack of clearly defined career path. Also, it severely lack institutionalized manpower creation environment, low or no investment in staff welfare, low participation of women, etc. This leads to less people opting for logistics jobs and high attrition rate, which results in improper and less recruitment. This has widened the gap between skill set required and skill set available for the industry. To have a world class logistics system, the prerequisite is the team that can run such system. Hence, it is required to improve the human resources available, which is influenced by the investment in human resources by government and the private sector. The most severe and immediate requirement for skill development is found to be in the road freight and warehousing segments [23].

\subsection{Importance of HR and skills development for efficient logistics}

A lot of studies have been conducted to study the role of human resources in logistics management and organizational performance. Delaney and Huselid [11] conducted a survey in 590 profit and non-profit firms and found that human resource management (HRM) practices like training, staff selectivity, and incentive compensation are positively related to perceptual measures of organizational performance. Sum [43] studied the effect and the role of training in business strategies and found that training function is a value-added source for sustained competitive advantage, and the training activities should be aligned with corporate objective and goals. Okeudo [33] conducted a study in Nigeria by collecting data from logistics service provider (LSP) and concluded that recruitment and selection, performance appraisal, training and development, health and safety of employee compensation and benefits have a significant and positive impact on firm performance. Also, that if these LSPs increase their human capital investment, by off and on job training, they will be able to improve their performance.

Ellinger et al. [12] conducted a study on 123 logistics service provider organization and concluded that 
employee-related activities such as service-related training and coaching influence both employee and organizational performance.

Wong and Karia [48] analysed profiles of fifteen LSPs through content analysis and concluded that it is not the number of employees that matter, but it is the competence and knowledge of human assets that deliver outstanding service and customer satisfaction. Ensuring continuous and desirable work outcomes of employees have strong relationship with their commitment to their organization; Acar [1] conducted a study on 344 employees of 37 Turkish logistics firms. This research supported the positive effect of organization culture on the organization commitment of the employee in the logistics industry. Gibson and Cook [14] surveyed 41 US 3PLs firm for hiring practices and recruiting, selection and compensation data, and recommending that the firms to use information to benchmark current practices. Kam et al. [22] explored the relationship between induction, recruitment and selection, performance management, reward management, and training and development with logistics capabilities and concluded that reward management, performance management and training and development are likely to reduce staff turnover and strengthen LSP's capabilities.

Anastasiou [3] states that HRM practices such as: training, work motivation, employee commitment, adaptability, empowerment, leadership, and shared values can positively contribute to supply chain success and encourage innovation with recognition and reward for managers, teams and individuals, leading to successful attainment of organizational goals.

Pandey et al. [34] conducted a survey in 60 automobile component manufacturing organizations in India to study the importance of human resource (HR) practices such as (training, collaborative performance systems and reward alignment) in achieving high levels of supply chain (SC) integration. The results indicated that information sharing has a significant effect on SC integration, and the relationship between these two variables is found to be positively moderated by 'training' and 'reward alignment', while 'collaborative performance systems' does not emerge as a significant moderator in the proposed relationships. Gorane and Kant [15] identified employee motivation, organization culture, teamwork and trust among employees, employee involvement, information communication technology (ICT) infrastructure and employee education training as most important supply chain enablers affecting all other factors, so the management should address these enablers cautiously. Not many studies have been done in India to study the effect of human resource management on logistics management. This research is an attempt to fill this gap, and on the basis of the above literature review, the following hypotheses are formulated:
$\mathbf{H}_{\mathbf{1}}$ : Skilled work force has a positive effect on corporate reputation building, recruitment, and retention of employees.

$\mathbf{H}_{2}$ : $\quad$ Skilled work force has a positive relationship with reduction in cost, reduction in time, improvement in reliability, flexibility, and safety of a logistics system.

$\mathbf{H}_{3}$ : $\quad$ Skilled work force has a positive relationship with logistics performance index.

$\mathbf{H}_{4}$ : Logistics performance index has a positive relationship with profit.

\section{Methodology}

\subsection{Case description}

$\mathrm{ABC}$ is an Indian based logistics company established in 1985 with an annual turnover of 1,200 crores. The company has a unified connectivity through air, road, and rail resulting in a plethora of offerings to its customers. It is the market leader in India and has a strong presence in Asia Pacific region and SAARC countries. It has a fleet of about 7,000 vehicles on road and 4,000 business partners in India. For services in India, the company relies heavily on the road transport segment.

With more and more multinational logistics service providers entering Indian market, the company is facing stiff competition and is striving hard to maintain its position. For reducing logistics cost, the company is trying to optimize its logistics process.

The company is facing huge losses through damages, high lead times and lower retention rate. After studying the various components of the process, it was found that major reasons for the increase in cost are improper handling, pilferage, redundant procedures, and lack of coordination. Also, there is a lack of proper procedure for recruitment of logistics staff. People switch to other jobs as soon as they get one because of improper working conditions. There is a lack of focus on the development of human resources and to tap the potential savings, which can be achieved through its improvement.

After a lot of brainstorming and convincing, the company has agreed to carry out this case study. To study the impact, it is necessary to develop a model that can show the dynamics between the enablers and results.

\subsection{Development of system dynamics model}

System dynamics is one of the efficient tools in real and dynamic conditions, which was developed by Forrester for the first time in 1950s and has grown rapidly in last 
50 years [13]. It is a computer-based simulation method that allows the modeller to graphically represent a system of differential nonlinear equations and to have the computer do the discrete-step computational effort over a preset time frame [27]. It is an approach to discover nonlinear dynamic behaviour and study structure and parameters of the system. The other main objective of it is designing the effective and stable policies that modify system performance. It also provides the possibility of testing new procedures and policies before performance [42].

The system dynamics approach begins with defining complex problems and uses different tools to reach its goals and to support decision-making processes. The tools are both qualitative (diagramming tools, as causal loop diagrams, stock and flow diagrams) and quantitative (formal model based on rigorous mathematical language, equations). For the present study, system dynamics modelling has been found appropriate to develop dynamic model for a case LSP.

\subsection{Causal loop diagram}

Causal loop diagrams are very effective systems thinking tool, which shows relationships between variables and also help to convert mental model into systems model. Variables are connected to each other with the help of arrows, to which polarity either negative or positive is assigned. A positive sign ' + ' means that if the cause increases or decreases, then the effect will also increase or decrease in the same direction. It is also known as reinforcing loop, which is denoted by ' $R$ '. A negative sign '-' means that if the cause increases or decreases, then the effect will increase or decrease in the opposite direction. It is also known as balancing loop, which is denoted by ' $\mathrm{B}$ '.

Figure 4 shows the causal loop diagram to study the impact of investment in human resources on development of skilled work force and its effect on LPI and Table 1 introduces all the variable used in development of causal loop diagram. The LSP will invest in human resources in training and improvement in service conditions. The training will be provided to office staff, truck drivers, warehouse managers, and loading staff. Through training, the skills of the worker will be improved. The service conditions will be improved by increased wages, improving working conditions, and welfare of the employee. This will improve the attractiveness of the sector and will lead to corporate reputation building. Corporate reputation will attract people to continue their jobs leading to high retention rate, leading to more skilled labour. Corporate reputation building will attract people to take up jobs in the sector and will lead to better recruitment. Better recruitment will enhance the image of the sector, which will improve the corporate reputation. So, closed loop between better recruitment and corporate reputation building is reinforcing. Also, better recruitment will also lead to skilled work force.

With the increase in the skill level of the workforce, cost will decrease. Since cost is an important factor in building the LPI, decrease in cost will lead to improvement in LPI. It is expected that improvement in LPI will generate more
Fig. 4 Causal loop diagram for impact of investment in HR on Logistics Performance Index

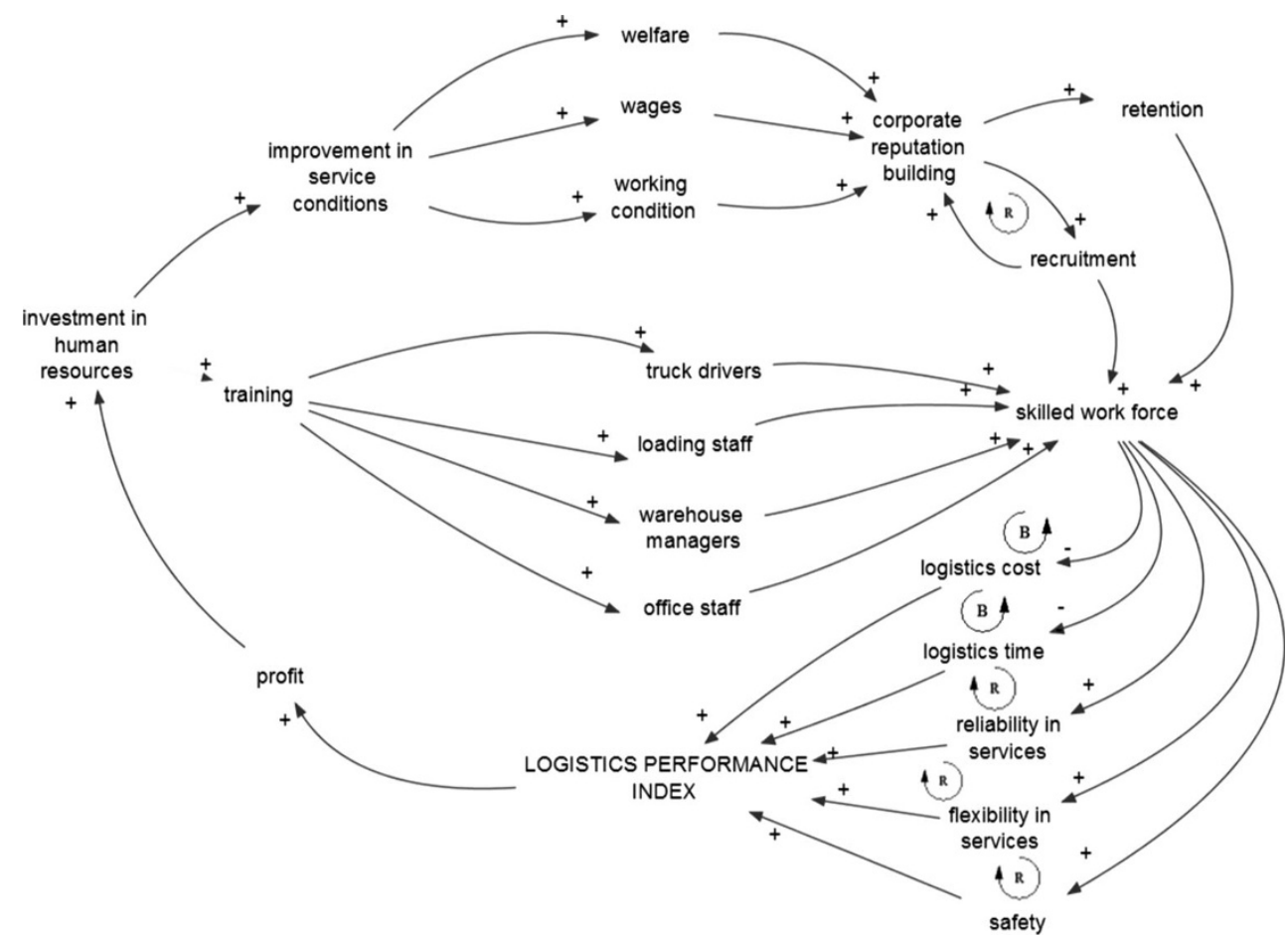


Table 1 Introduction to variables used in causal loop diagram

\begin{tabular}{|c|c|c|}
\hline Variable & References & Description \\
\hline Investment in human resources & KPMG [23] & $\begin{array}{l}\text { Investment done in human resources by } 3 \mathrm{PL} \text { to improve service conditions } \\
\text { and provide training }\end{array}$ \\
\hline Training & $\begin{array}{l}\text { Chandra and Kumar [9], } \\
\text { Gowen and Tallon [16] }\end{array}$ & $\begin{array}{l}\text { Training imparted to truck drivers, loading supervisors, warehouse managers, } \\
\text { office staff, logistics managers }\end{array}$ \\
\hline $\begin{array}{l}\text { Improvement in service } \\
\text { conditions }\end{array}$ & Okeudo [33] & $\begin{array}{l}\text { Improving the conditions under which the logistics personnel work which is } \\
\text { the biggest hindrance for people not opting for logistical jobs }\end{array}$ \\
\hline $\begin{array}{l}\text { Welfare/wages/working } \\
\text { conditions }\end{array}$ & $\begin{array}{l}\text { Ellinger et. al [12], Prowse and } \\
\text { Prowse [35], Vonder gracht } \\
\text { et. al [47] }\end{array}$ & $\begin{array}{l}\text { Investing money or forming policies for welfare of the employee, improving } \\
\text { wages of the employees and the harsh and unhygienic conditions under } \\
\text { which they work }\end{array}$ \\
\hline $\begin{array}{l}\text { Staff-truck drivers, loading } \\
\text { staff, warehouse managers, } \\
\text { office staff }\end{array}$ & KPMG [23] & Categories of people required for doing logistical work \\
\hline Corporate reputation building & KPMG [23] & $\begin{array}{l}\text { The positive image of the company which increases investment by } \\
\text { shareholders, retain and attracts good talent }\end{array}$ \\
\hline Retention & $\begin{array}{l}\text { Min and Emam [29], } \\
\text { Bhatnagar [6] }\end{array}$ & Reduction in employee turnover \\
\hline Recruitment & Gibson and Cook [14] & Attracting suitable and skilled candidates to apply for logistical jobs. \\
\hline Skilled work force & Mitra [30] & $\begin{array}{l}\text { Workforce which is equipped with the skills required to perform the jobs } \\
\text { better and in efficient manner }\end{array}$ \\
\hline Logistics cost & Somuyiwa [40], Rahman [36] & Cost required to carry out logistics operations \\
\hline Logistics time & Sauvage [38] & Total time required to carry out logistics services \\
\hline Reliability in services & Islam et. al [21] & A consistent system which work effectively under different conditions \\
\hline Flexibility in services & $\begin{array}{l}\text { Zhang et. al [49], Naim et. al } \\
\text { [32] }\end{array}$ & Ease with which the system can respond to uncertainty and quick response \\
\hline Safety & Cantor [7] & A system which is less prone to accidents, damages and other losses \\
\hline Profit & $\begin{array}{l}\text { Stapleton et. al [41], Randall et. } \\
\text { al [37] }\end{array}$ & A positive gain from a business after subtracting all the expenses \\
\hline
\end{tabular}

trade and thus revenue for LSP a part of which will be reinvested more in further training, development and welfare of human resources. Therefore, the loop between investments in HR, training or improvement in service conditions, skilled labour, cost, LPI and profit is balancing. Skilled work force will reduce the time for doing logistics activities, which will also improve the LPI. So, the loop between investments in HR, training or improvement in service conditions, skilled labour, time, LPI and profit is also balancing. Skilled labour will also improve the reliability, flexibility and safety of the system. Therefore, the loops between investment in HR, training or improvement in service conditions, skilled labour, reliability or flexibility or safety, LPI and profit are all reinforcing loops. There are four reinforcing loops and two balancing loops.

\section{Result and discussions}

The causal loop diagrams help to create the flow diagram, which are the ultimate diagramming aid that represents the feedback structure in terms of physical and information flows and stocks and are also known as stock and flow
Table 2 Description of important system dynamics components Source [45]

\begin{tabular}{|c|c|c|c|}
\hline S.No. & $\begin{array}{l}\text { Variable } \\
\text { name }\end{array}$ & Symbol & Description \\
\hline 1. & Level & & $\begin{array}{l}\text { It accumulates changes and is } \\
\text { influenced by flows }\end{array}$ \\
\hline 2. & Auxiliary & $\bigodot_{\text {Auxiliary }}^{(}$ & $\begin{array}{l}\text { A variable type, which } \\
\text { contains calculations based } \\
\text { on other variables }\end{array}$ \\
\hline 3. & $\begin{array}{l}\text { Flow } \\
\text { with } \\
\text { rate }\end{array}$ & & $\begin{array}{l}\text { It influences levels. The flow } \\
\text { is controlled by the } \\
\text { connected rate variable, } \\
\text { normally an auxiliary } \\
\text { variable }\end{array}$ \\
\hline
\end{tabular}

diagrams [44]. The important components used to develop the stock and flow diagram are shown in Table 2.

The stock and flow diagram has been developed as shown in Fig. 5 using STELLA 9.1.3 software. After developing the stock and flow diagram, the model has been simulated by taking 2012 as a base year as this study was initiated in that year and simulation is run for next 12 years, taking the value of DT (Delta Time) as one. Delta 


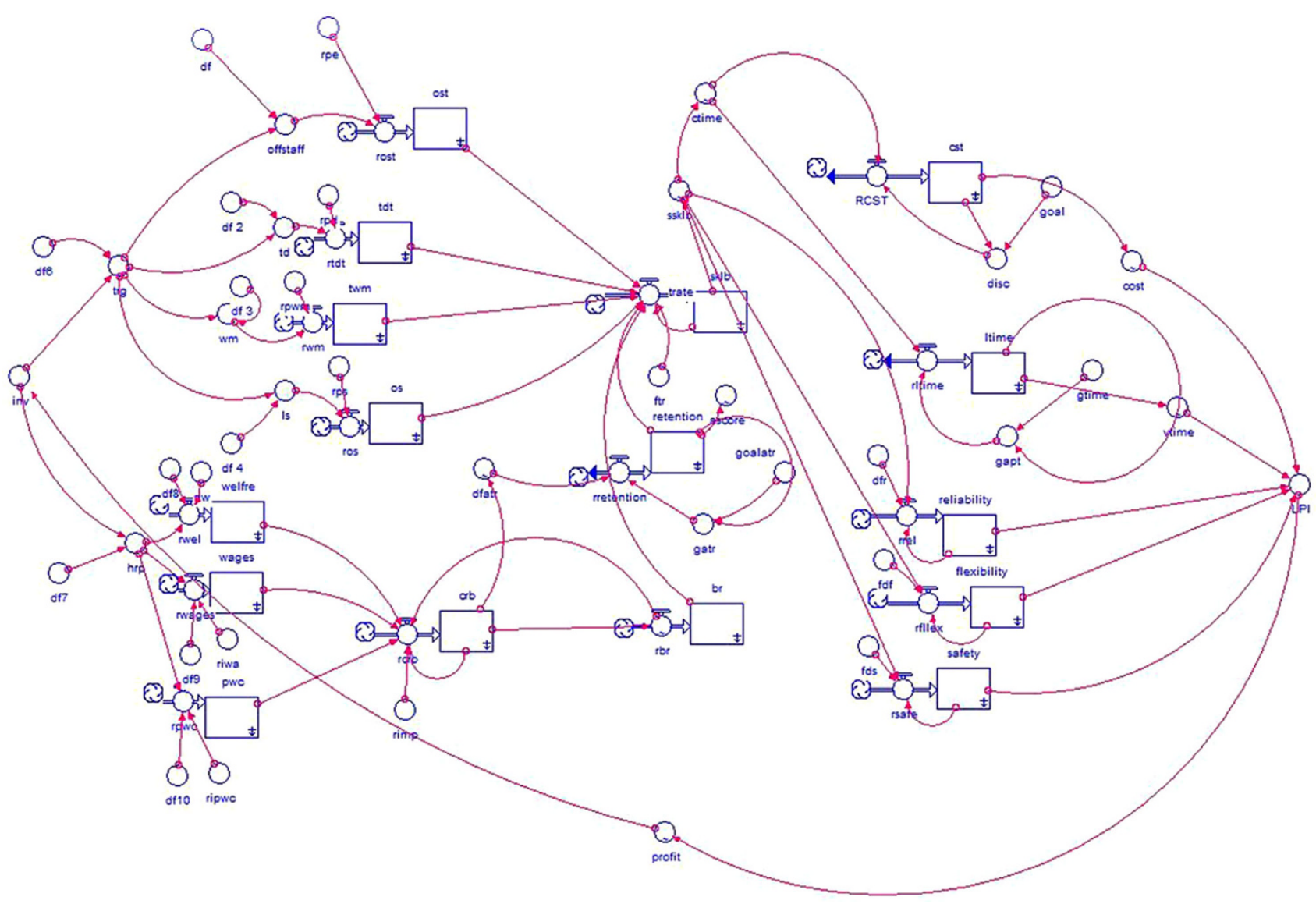

Fig. 5 Stock and Flow diagram for development of skilled work force and measurement of Logistics Performance Index

Table 3 Rating of score for variables

\begin{tabular}{llllll}
\hline Factor & Score & & & & \\
\cline { 2 - 5 } & 1 & 2 & 3 & 4 & 5 \\
\hline Corporate reputation building & Extremely bad & Quite bad & Good & Quite good & Extremely good \\
Recruitment & Extremely bad & Quite bad & Good & Quite good & Extremely good \\
Skilled work force & Introduced & Practiced & Skilled & Advanced & Expert \\
LPI & Poor & Fair & Good & Very good & Excellent \\
\hline
\end{tabular}

time controls how frequently calculations are applied each unit of time and as their process will not change every unit of time, it is taken as one in this case. The company agreed to invest Rs. 10 crores for improving the conditions of human resources. Among which $20 \%$ was invested in training and $80 \%$ in welfare, wages and improvement in working conditions. The scores of all the parameters in calculated out of five. Score is the rating of the particular variable on the scale of one to five. Table 3 indicates the rating of each score for various variables studied in the paper.

Figure 6 shows the relationship between skilled labour, retention, recruitment and corporate reputation building (CRB). The total labour trained is 18,168 out of about
50,000 employees i.e. $36 \%$ employees were trained, taking average training cost per employee as Rs.12,000 only. The score of CRB is 2.8 out of five. Due to this, retention is improved by $58 \%$ and the score of recruitment was 4.4. As the company started improving the working conditions, wages and welfare of the employees, people started opting for jobs in this company and better people were available for recruiting. As the attrition rate also reduced, so there is a high retention of skilled and experienced labour. With the focus on improving the working conditions and overall welfare of the employees, the company will get a facelift. Therefore, $\mathrm{H}_{1}$ stating skilled work force has a positive effect on corporate reputation building, recruitment and retention of employees can be accepted. 


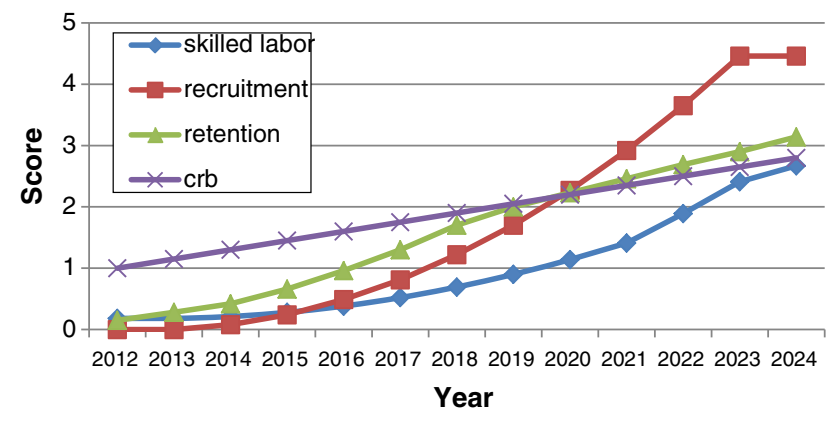

Fig. 6 Improvement in skills, recruitment, retention and corporate reputation building due to skilled work force

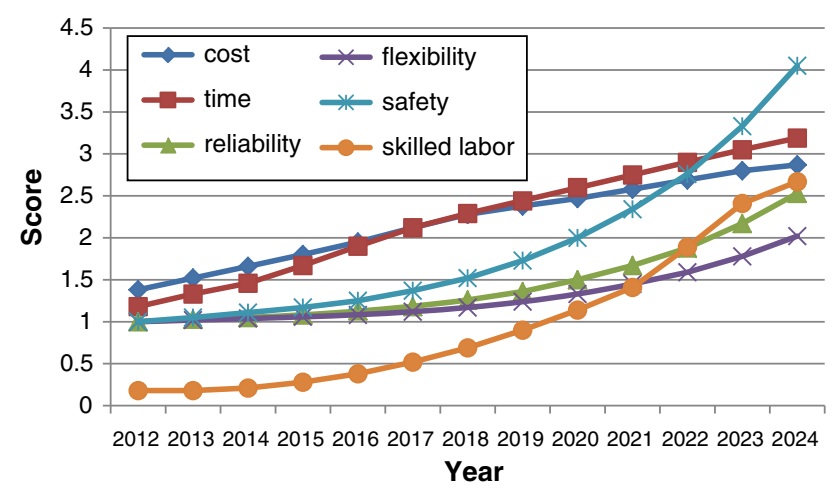

Fig. 7 Improvement in logistics cost, logistics time, reliability, flexibility and safety due to skilled work force

Figure 7 discusses the improvement in results in the period of 12 years. With an investment of ten crores and in the period of 12 years, the score of cost reaches 2.87 and the reduction in cost is $12 \%$. The score for time is 3.2 and the reduction in time is $80 \mathrm{~min}$ a day. The score for reliability, flexibility and safety are 2.53, 2.02 and 4.05 respectively. Human resource is an important factor in logistics, but the logistical system is dependent on many other factors such as infrastructure, government regulations, use of information technology. Flexibility is influenced by the logistics infrastructure and use of information technology more than human resources. Therefore, the score is the lowest. Proper training leads to reduction in accidents, maintenance of the vehicle, proper handling of the goods, etc. Also, due to improvement in the image of the sector, better qualified drivers will be recruited, which will also reduce the number of accidents. So the score of safety is highest and has major contribution in LPI. Therefore, we accept $\mathrm{H}_{2}$ stating skilled work force has a positive relationship with reduction in cost, reduction in time, improvement in reliability, flexibility and safety of a logistics system.

Figure 8 shows the graph between skilled labour and logistics performance index. The score of LPI is 2.93 out of 5 and score of skilled work force is 2.7 out of 5 . With more investment, these scores can be improved. This shows that

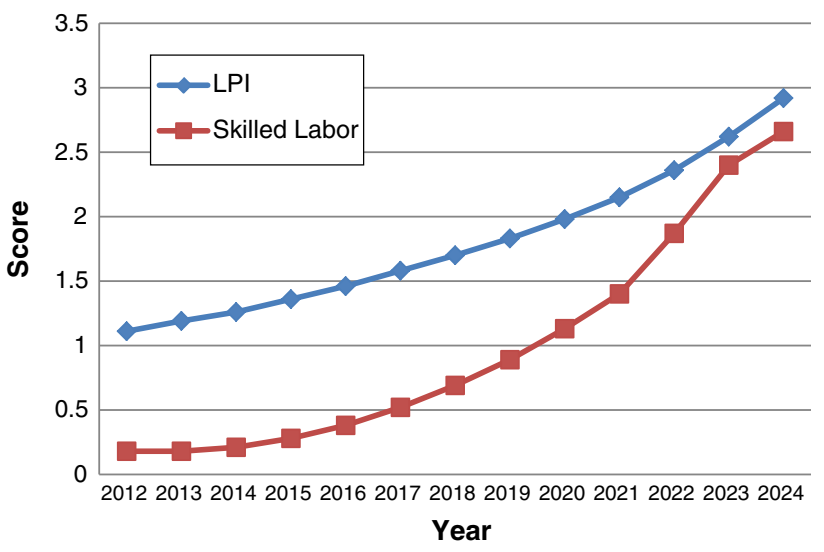

Fig. 8 Improvement in LPI due to skilled work force

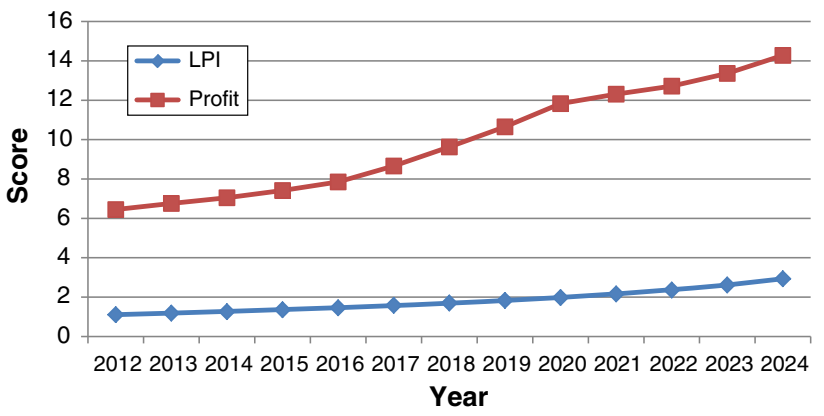

Fig. 9 Improvement in profit and logistics performance index due to investment in HR

development of skilled work force has a positive relationship with the LPI and $\mathrm{H}_{3}$ can be accepted that skilled work force has a positive impact on LPI.

Figure 9 shows the relationship between LPI and profit. With the improvement in LPI the profit also increases. The score of profit is in terms of percentage increase in profits. Increase in profit can be influenced by reduction in cost, improvement in safety thus increasing the revenues. Increase in profit will lead to more investment, leading to more skilled labours. So we accept $\mathrm{H}_{4}$ that logistics performance index has a positive relationship with profit.

As stated earlier, LPI is influenced by many other factors. Therefore, to improve the logistics performance index, other factors will also have to be involved. Although the index has considerably improved, but when other factors like use of information technology, reduction in taxes by the government, proper logistics policies will be involved, then the interplay of all these factors will give the highest LPI.

\section{Conclusion}

The present study demonstrates the effect of skilled work force on the logistics performance of an organization using system dynamics methodology. Skilled work force can also 
be developed by improving the service conditions and providing training to the employees. Improvement in service conditions will attract more people to join logistics industry and also will increase the retention rate. Attracting more people will provide better options for recruitment thereby increasing skilled labour.

Availability of skilled manpower can improve the logistics performance significantly leading to reduction in logistics cost, logistics time, and making the system more reliable and safe. Although flexibility is not directly affected by skilled labour, but to achieve flexibility, strong infrastructure and ICT backup is required, which would be difficult to run without skilled labour.

Reduction in time, cost, losses, and accidents will improve the reliability of the logistics system and also improve the profits. More profits will help to invest more in development of human resources, which will lead to more improvement in LPI.

With the help of this case study, the authors try to prove that skilled work force has a strong relationship with the performance of any logistics system. Companies the world over are focussing on exploring the skills and competencies required by today's logistics professionals to tackle the information intensive and dynamic market conditions and still there is huge gap in the demand and supply of the professionals required. To cater to this, the logistics companies need to make sure that a strong commitment to addressing human resources challenges and commitment for improving the sector's comes should come straight from the top [47].

Managers should concentrate on training their workforce and recruiting skilled labour. Policy makers should concentrate on building training schools and forming policies so that the condition of human resources improves and more people opt for logistics jobs. Organizations should concentrate on improving the working condition and welfare of the employees to improve the image of the sector attracting better talent. The model can be simulated further to generate various scenarios under different investment plans and in different sector.

Open Access This article is distributed under the terms of the Creative Commons Attribution License which permits any use, distribution, and reproduction in any medium, provided the original author(s) and the source are credited.

\section{References}

1. Acar A (2012) Organizational culture, leadership styles and organizational commitment in Turkish logistics industry. Procedia-Soc Behav Sci 58:217-226 Accessed 1 May 2014

2. Alexander J, Goyal A, Dave A, Desai M, Vignesh P (2013) A speculative study on skill gaps in logistics industry-Indian perspective. Social science research network. Retrieved from http://ssrn.com/abstract=2241116
3. Anastasiou S (2012) Critical human resources management functions for efficient logistics and supply chain management. In: Proceedings of the 2nd International Conference on Supply Chains, Katerini, Greece, 2012

4. Arvis J, Mustra M, Panzer J, Ojala L, Naula T (2007) Connecting to compete: trade logistics in the global economy. http://siter esources.worldbank.org/INTTLF/Resources/lpireport.pdf. Accessed 12 June 2013

5. Arvis J, Mustra M, Panzer J, Ojala L, Naula T (2012) Connecting to compete: trade logistics in the global economy. http://siter esources.worldbank.org/TRADE/Resources/23907013366549661 93/LPI_2012_final.pdf. Accessed 12 June 2013

6. Bhatnagar J (2007) Talent management strategy of employee engagement in Indian ITES employees: key to retention. Empl Relat 29(6):640-663

7. Cantor D (2008) Workplace safety in the supply chain: a review of the literature and call for research. Int J Logist Manag 19(1):65-83

8. Celebi D, Bayratkar D, Bingol L (2010) Analytical network process for logistics management: a case study in a small electronic appliances manufacturer. Comput Ind Eng 58(3):432-441

9. Chandra C, Kumar S (2000) Supply chain management in theory and practice: a passing fad or a fundamental change. Ind Mana Data Syst 100(3):100-113

10. Damadaran H (2013) India's GDP growth estimate. The Hindu Business Line. http://www.thehindubusinessline.com/opinion/col umns/indias-gdp-growthestimate/article4375345.ece

11. Delaney J, Huselid M (1996) The impact of human resource management practices on perceptions of organizational performance. Acad Manag J 39(4):949-969

12. Ellinger A, Ketchen G, Hult G, Elmadag A, Richey R (2008) Market orientation, employee development practices, and performance in logistics service provider firms. Ind Mark Manag 37(4):353-366

13. Forrester JW (2007) System dynamics: a personal view of the first fifty years. Syst Dyn Rev 23(2/3):345-358

14. Gibson B, Cook R (2001) Hiring practices in US third-party logistics firm. Int J Phys Distrib Logist Manag 31(10):714-732

15. Gorane S, Kant R (2013) Modelling the SCM enablers: an integrated ISM-fuzzy MICMAC approach. Asia Pac J Mark Logist 25(2):263-296

16. Gowen C, Tallon W (2003) Enhancing supply chain practices through human resource management. J Manag Dev 22(1):32-44

17. Green K, Whitten D, Inman R (2008) The impact of logistics performance on organizational performance in a supply chain context. Supply Chain Manag: An Int J 13(4):317-327

18. Gunasekaran A, Ngai E (2003) The successful management of a small logistics company. Int J Phys Distrib Logist Manag 33(9): $825-842$

19. Hall M, Hall C, Rigsbee C (2013) Strategic human resource management and supply chain orientation. Hum Resour Manag Rev 23(4):366-377

20. Indexmundi (2011) Historical data graphs per year. http://www. indexmundi.com/g/g.aspx?c=xx\&v=66. Accessed 1 May 2014

21. Islam D, Meier J, Aditjandra P, Zunder T, Pace G (2013) Logistics and supply chain management. Res Transp Econ 41(1):3-16

22. Kam B, Tsahuridu E, Ding M (2010) Does human resource management contribute to the development of logistics and supply chain capabilities? An empirical study of logistics service providers in China. Res Pract Hum Resour manag 18(2):15-34

23. KPMG (2008) White paper on skill gaps in the Indian logistics. http://www.kpmg.de/docs/Skill_gaps_in_the_Indian_Logistics_ Sector_A_white_paper.pdf. Accessed 1 May 2013

24. Kunadhamraks P, Hanaoka S (2007) Evaluating the logistics performance of intermodal transportation in Thailand. Asia Pac J Mark Logist 20(3):323-342 
25. LCL Logistix (India) Pvt. Ltd (2011) Whitepaper on human resource shortfall in the Indian logistics sector. http://www.lcllo gistix.com/pdf/white_paper.pdf. Accessed 25 July 2013

26. Mangan J, Lalwani C, Butcher T (2008) Global logistics and supply chain management. Wiley, Wiltshire

27. Marco A, Rafele C (2007) System dynamics simulation: an application to regional logistics policy making. Int J Math Mod Methods Appl Sci 1(4):253-260

28. Mckinsey (2010) Building India transforming the nation's logistics infrastructure. http://www.mckinsey.com/locations/ india/mckinseyonindia/pdf/Logistics_Infrastructure_by2020_full report.pdf. Accessed 25 April 2014

29. Min H, Emam A (2003) Developing the profiles of truck drivers for their successful recruitment and retention. Int J Phys Distrib Logist Manag 33(2):149-162

30. Mitra S (2006) A Survey of the third-party logistics (3PL) service providers in India. IIMB Manag Rev 18(2):159-183

31. Mitra $S$ (2008) Logistics industry: global and Indian perspectives. Glob Bus Econ Anthol Bus Econ Soc Int 2:130-138

32. Naim M, Potter A, Mason R, Bateman N (2006) The role of transport flexibility in logistics provision. Int $\mathrm{J}$ Logist Manag 17(3):297-311

33. Okeudo G (2012) The impact of human resources management in logistic service providers and supply chain capabilities: a case study. Br J Sci 4(1):57-71

34. Pandey P, Bhattacharyya S, Kaur A (2012) Exploring the role of HR practices in supply chain. J Adv Manag Res 9(1):113-123

35. Prowse P, Prowse J (2010) Whatever happened to human resource management performance. Int J Prod Perform Manag 59(2):145-162

36. Rahman Z (2004) Use of internet in supply chain management: a study of Indian companies. Ind Manag Data Syst 104(1):31-41

37. Randall W, Farris M (2009) Supply chain financing: using cashto-cash variables to strengthen the supply chain. Int J Phys Distrib Logist Manag 39(8):669-689
38. Sauvage $T$ (2003) The relationship between technology and logistics third-party providers. Int J Phys Distrib Logist Manag 33(3):236-253

39. Shang K, Marlow P (2007) Logistics capability and performance in Taiwan's major manufacturing firms. Transp Rep Part E 41:217-234

40. Somuyiwa A (2010) Analysis of transportation cost in overall logistics cost management of manufacturing companies in southwestern, Nigeria. Eur J Sci Res 44(3):420-429

41. Stapleton D, Hanna J, Yagla S, Johnson J, Markussen D (2002) Measuring logistics performance using strategic profit model. Int J Logist Manag 13(1):89-107

42. Sterman JD (2010) Business dynamics (system thinking and modelling for a complex world). Mc Graw-Hill Higher Education, Delhi

43. Sum V (2011) Integrating training in business strategies means greater impact of training on the firm's competitiveness. Res Bus Econ J 4:1-19

44. Sushil (1993) System dynamics a practical approach for managerial problems. Wiley Eastern Limited, New Delhi

45. Verma P (2004) Dynamic modelling for emission control policies in the delhi urban transport system. Dissertation Indian Institute of Technology Delhi

46. Viswanadham N, Gaonkar R (2001) Whitepaper on industrial and logistics development strategy for India. The Logistics InstituteAsia Pacific, Singapore

47. Von der Gracht H, Gnatzy T, Ecken P, Darkow I (2012) Transportation and logistics 2030. Eur Foresight Platf 60(39):59

48. Wong C, Karia N (2009) Explain the competitive advantage of logistics service providers. Int Prod Econ 28:51-67

49. Zhang Q, Vonderembse M, Lim J (2005) Logistics flexibility and its impact on customer satisfaction. Int $\mathbf{J}$ Logist Manag 16(1):71-95 